\title{
Feminine Sensibility In Anita Desail'S Cry,The Peacock
}

\author{
Bilquees Dar
}

\section{Introduction}

Feminism is a collection of movements and ideologies armed at defining, establishing and defending equal political, economic and social rights for women. French Philosopher Charles Fourier is credited with having originated the word in 1837. It is a global and revolutionary ideology as well as a socio-cultural movement that aims at the freedom of woman from male domination in the patriarchal society. It highlights various hidden and oppressive aspects of man - woman relationship. It has a profound impact on the debate concerning the relation between genders, culture and creativity and knocks down the claims of certain cultures, which believe that woman can only produce children and not art. This movement fought for the issues related to women like gender discrimination male domination, oppressive culture, domestic violence, sexual harassment, reproductive rights, property right equal salary, equal opportunities for career and business, liberation and empowerment of women.

It has swept the world and has brought a tremendous change in the status of women across the world. This movement began in the western world in the late $19^{\text {th }}$ century and hasgone through three waves. First wave feminism was oriented around the station of middle or upper class women and involved suffrage and political equality. Second wave feminism attempted to further combat social and cultural inequalities. Third wave feminism includes renewed campaign for politics. The feminist apprehends certain features of social reality as intolerable as to be rejected if one is to transform society for a better future. The themes included in feminism include patriarchy, sexual objectification and oppression and studies a structural inequality. One of the most structural expression of the movement was Mary Woll Stone Craft's, A Vindication of the Rights of Women (1792). The 1848 'Seneca Falls Convention' convened by Elizabeth Cady Stanton, Lucretia Mote and others called for full legal equality with men, including full educational opportunity and equal compensation; thereafter women suffrage movement began to gather momentum. The term Feminism can also be used to describe an academic discourse or to describe a political social or economic movement aimed at more rights and legal protection for women. Though Feminism has been defined in different ways, but it is agreed that it encompasses a set of beliefs, values and attitudes centered on the high evaluation of women as human beings

INDEX WORDS: Feminism, Feminine Sensibility, Female Dilemma, liberation, Patriarchy.

\section{Anita Desai}

Anita Desai is a prolific living writer churning out fiction with consummate skill who has brought out ten full-length novels of varied length, innumerable short stories and couple of write ups. In a short period of time, she aroused a lot of critical attention. She is considered the writer who introduced the psychological novel to India and is pioneer of writing on feminist issues. She dealt her fiction with feminine sensibility and her themes are innovative, mostly about miserable plight of women suffering under their insensitive and inconsiderate husbands, fathers and brothers. Though Anita Desai attempts to analyse Feminine Consciousness in her fiction however, she has been particularly cautious of labels and refuses to see herself as a feminist. Mostly shepotrays a world of a dissatisfied woman who is a lonely protagonist. She challenges the prevalent version of Indian women stereotype by subverting their quest for fulfillment with an intense dissatisfaction with the family system hence a resultant unsatisfied ego. Desai's women are mostly in self-search and in search of fulfillment of the emptiness they feel even in ties between parents, siblings, friends and yet incomplete. Desai has created a feminist discourse of literary writings showing signs of a seething discontentment, hatred for the patriarchal norms of civilized human existence, aspirations for liberation from societal and traditional family norms made compulsory for their acceptable existence in the mainstream male dominated society. Her family characters are mostly in search of self- authenticity, independent of the identity that has been dumped on her. Desai has a typical style of her own to register protest against patriarchal norms. Her characters are usually women, haunted by peculiar sense of doom, so withdraw themselves into a sequestered world of their own, become neurotic, self-destructive and unhappy.

* University of Kashmir 
Anita Desai does not deal with such problems which are totally the purview of a feminist thinker. There lies a deeper distinction between feminine sensibility and feminine approach. She does not hesitate to pin point the equal responsibility of female characters. While a feminist tries to see only the suppression, oppression, cruelties and injustices did to the woman kind in the past and links these phenomena with the present. Like Virginia Woolf of western literary paradigm, Desai has created woman characters who are more and more symbolic, subverted and suppressed. They are human beings who seek liberation, move from bondage to freedom, from indecision to self-assertion, from weakness to strength.

\section{Feminine Sensibility In Cry Of The Peacock}

Anita Desai's 'Cry The Peacock is a unique example or an illusion of the feminist point of view. She defines the uniqueness of feminine sensibility through the reactions and responses of the heroine to the events and situations in the novel. A highly emotional, sensitive and sensuous woman, Maya has obsessive love for life, she is perfectly normal and healthy woman. Her only sin is that she is sensitive, imaginative, passionate and sensuous and thus represents the disturbed psyche of modern Indian woman. She tries to strike balance between institutional needs and intellectual aspirations and is deeply bewildered when the existential absurdity of life is brought before her. When she experiences loneliness and lack of communication, she feels herself in mental crisis. She is seen to share a very affectionate relationship with her father and is at pain to leave her home at marriage. Her problem upbringing caused by her mother's death makes her detached from the world outside. Thus she wrote, “... my childhood was one in which much was excluded, which grew steadily more-restricted, unnatural even, in which I lived as a toy princess in a toy world. But it was a pretty one. The expectations she had at marriage of her husband, who is much older than her are not fulfilled. As a result, she becomes stultifying. She funds her husband Gautama, as a man in whom understanding was scant, love was meagre.But as one reads through the novel, one funds that her husband loves and cherishes her, but does not take her seriously and that too because she is a woman. He identifies her with "Maya", which repulses her and to which she objects. As time passes, she becomes more and more restless, starts brooding over the feeling of emptiness in her heart. She says,

.. I had yearned for the contact that goes deeper than flesh - that of thought - and longed to transmit to him, the laughter that gurgled up in my throat as I saw a goat nuzzle secretly a basket of sliced melons in the bazaar while the vendor's back was turned or the prolonged thrill that lit a bonfire in the pit of my stomach when I saw the scene unfurl like a rose in the west and farther west ... But those were the times when I admitted to the loneliness of the Human soul, and I would keep silent.'

Maya is thus an extremely sensitive character, a portrayal of woman who has failed to come to terms with Hegemony and patriarchal order. Though she lives in the male world surrounded by male dominancy, she refuses to identify with it and revolts against it in her own way. As the story unfolds, she seeks her mother in the natural landscapes and gardens, gets solace in it, but her inner feelings and deepest desires would not be rejected. Though Maya is an affluent housewife with all the necessities of a comfortable city life fulfilled ,yet she is neither happy nor satisfied nor is she the ideal, content housewife who compromises with her situation and thus suppressing her self-identity and feminine desire in her heart till she dies.

Maya is a rebel woman who fails to identify herself with her husband Gautama's world and finds herself alienated from the affection she got from her father and besides her total economic dependence on her husband makes her feel rather insecure and powerless. There are other traits in Maya's character which transcends the idea of Feminity. She is in search of new vista for a woman's world, a space in which she is at par with man. The dance of the peacock's who destroy each other in spite of being madly in love. Maya thinks of her married life with Gautama as a deadly struggle in which one is destined to kill the other. Rebuffed by her husband, Maya is torn between her lone of life and her fear of death. She is deeply stricken with the sense of loneliness and insecurity, she says,

"God, now I am caught in the net of the inescapable, and where lay the possibility of mercy, of release'. This net is no hallucination, no. Am I gone insane? Father! Husband, Who is my savior? I am in need of one. I am dying and I am in love with living, I am in love and I am dying, God, let me sleep, forget me, But no I'll never sleep again. There is no rest any more only death and waiting.'

\section{References}

[1]. Pathok, R. (1991). Beyond the He-Man Approach: The Expression of Feminine Sensibility in Anita Desai's Novels, Feminism and Recent Fiction in English, Refrences ed. Sushila Singh, New Delhi: Prestige Books.

[2]. Bande, U. (1988). The Novels of Anita Desai, New Delhi: Prestige Books.

[3]. Desai, A. (2006). Cry, the Peacock Delhi: Orient Paperbacks.

[4]. Deshpande, S. (1983). Roots and shadows, Hyderbad: Orient Paperbacks.

[5]. Sharma, P.S. (1981). Anita Desai, Arnold - Helneman, New Delhi.

[6]. Singh, S. (1970). 'Recent Trends in Feminist thought: A Tour de Horizon, Feminism, Theory, Criticism, Delhi: Analysis Pencraft International. 
[7]. Tarika, S.(1993). A Book of Her Own: A Biography of a Nineteenth Century Woman, History Workshop, No. 36, Colonial and PostColonial History.

[8]. Cariffithsm, S. (1996). Beyond the Class ceiling; Forty woman whose idea shape the world. Manchester: Manchester University Press.

[9]. Desai, A. (1980). A clear light of the day London: Penguin Books 1980

[10]. Desai, A. (1979). Interview with Anita Desai by YashodaraDalmia, The Times of India

[11]. Sharma, R. (1981). Anita Desia, Arnold Heinemann, New Delhi.

[12]. Deshpande, S. (1983). Roots and Shadows, Hyderabad: Orient Paper.

[13]. Kate, M. (1969).Sextual Politics. London: Rupert Hart, dans.

[14]. Meena, B. (1971). Anita Desai: A study in her Fiction (Ninth Writers Workshop). 